\title{
A STRATEGY FOR THE ADRIATIC AND IONIAN MARITIME REGION: THE MAKING OF A MACRO-REGION ACROSS THE EU BORDER
}

Regina SALVADOR

CICSNOVA - Faculdade de Ciências Sociais e Humanas da Universidade NOVA de Lisboa

regina.salvador@fcsh.unl.pt

\begin{abstract}
Resumo
O presente texto descreve a Estratégia da União Europeia para a Região Marítima dos mares Adriático e Jónico (RMUEAJ). As estratégias das Bacias Marítimas da UE sobrepõem-se parcialmente com as das Macro-Regiões, como acontece no caso das Regiões do mar Báltico e do Danúbio.

Este mecanismo combinado está a criar uma mega-região europeia, cuja estratégia de crescimento económico se baseia nas ligações de transportes terra-mar, na conectividade energética, na protecção ambiental e no turismo sustentável. A particularidade mais interessante é ser esta a primeira estratégia macro-regional que incorpora tanto Estados-Membros da UE (Croácia, Grécia, Itália e Eslovénia) como não EM's (Albânia, BósniaHerzegovina, Montenegro e Sérvia).
\end{abstract}

Palavras-Chave: Região Marítima dos mares Adriático e Jónico. RMUEAJ. Estratégias das Bacias Marítimas da UE. Estratégias das Mega-Regiões da UE.

\section{Abstract}

The paper describes the European Union Strategy for the Adriatic and Ionian Maritime Region (EUSAIR). The EU Sea Basins Strategies partially overlap those of the Macro-Regions, as it was the case in the Baltic Sea and the Danube Regions.

This combined mechanism is creating a maritime mega-region, whose economic development approach is based in the land-sea connection transports, energy connectivity, marine environment protection and sustainable tourism. The most interesting particularity of EUSAIR is that it is the first Macro-Regional Strategy that incorporates both EU Member States (Croatia, Greece, Italy, and Slovenia) and non-MS (Albania, Bosnia and Herzegovina, Montenegro and Serbia).

The main vulnerabilities of the region are displayed: socio-economic disparities, institutional weaknesses, infrastructural deficit, and ecological issues. About the latter (the Adriatic and lonian seas are considered to be the most endangered area of the Mediterranean) a series of maritime problems are dealt: water pollution, high level of coastal urbanisation, lack of fish stocks. Good practices in other EU Member States with similar problems are presented.

Keywords: Adriatic and Ionian Region. EUSAIR. EU Sea Basins Strategies. EU Mega-Region Strategies.

\section{Introduction}

In 2005, the European Commission began developing the Integrated Maritime Policy (IMP) to manage maritime affairs with a radically new approach. The IMP arose from the need for a holistic 
approach to the seas and oceans, in the face of renewed environmental challenges and global economic competition. This integration of maritime affairs recognises its importance in the socioeconomic development of Europe, which counts $70,000 \mathrm{~km}$ of coastline. The EU coastal regions are also home to $40.8 \%$ of the EU-27 population, and where approximately $40 \%$ of the EU's GDP is generated (EUROSTAT, 2018).

The policy framework seeks to systematically connect and coordinate (rather than replace) maritime sectors, previously operating independently. It focuses on five branches - aquaculture, coastal tourism, blue biotechnology, ocean energy and seabed mining. According to the keynote speech that launched the IMP, José Manuel Barroso (2007) stated that with this policy "Europe can draw much higher returns with a far lesser impact on the environment".

The IMP strategy is multifold including, among others, the following transversal subjects: blue growth, marine data and knowledge, maritime spatial planning, integrated maritime surveillance and sea basin strategy. In this paper one focus in particular the case of the Adriatic and Ionian Sea Basin strategy.

\section{The Maritime European Union Basins}

The Sea Basins Strategy partially overlap that of the Macro-Regional Strategy - an integrated framework of cooperation endorsed by the European Council, based on creating synergies and coordination in order to face common problems (i.e. pollution, navigability, global commercial competition, etc). Most of the macro-regions identified surround a large body of water: Baltic Sea Region (adopted in 2009), Danube Region (adopted in 2010), Adriatic and lonian Region (adopted in 2014). The Alpine Region, which is the only designated region not surrounding a sea, was adopted in 2015. In some cases, the IMP Basin Strategy is implemented through the macro-regional approach as they both focus on similar agendas due to the geographical constitution of the region.

For instance, the Sea Basin Strategy for the Baltic Sea adopted the previously existing cooperation structure and multi-sector dialogue developed with the Macro-Regional Strategy (created in 2009). In fact, the policy for this area (EUSBSR) identified challenges and actions directed to save the sea that connects the eight Member-States of the Baltic sea region (Sweden, Denmark, Estonia, Finland, Germany, Latvia, Lithuania and Poland). It helped to mobilise funds in order to finance institutions and non-governmental bodies to promote a more balanced development of the Baltic Sea Region.

Also in the case of the Adriatic and Ionian Seas, there is a combined mechanism between the IMP's Basin Strategy and the Macro-Regional Strategy, which has been created hand-in-hand between 2012 and 2014. We explore the making of this maritime mega-region in the next chapter. 


\section{Macro-Regional Strategies and Sea Basin Strategies}

The Sea Basin Strategy delineated by the IMP for the area surrounding the Adriatic and Ionian Seas was adopted in 2014. It revolves around the maritime economy opportunities - "blue growth", land-sea connection transports, energy connectivity, marine environment protection and sustainable tourism. These are considered as "sectors ... to create jobs and boost economic growth in the region" (European Commission, 2014).

This strategy emerged from a new, broader and more systematic conception of the previous practices of cooperation implemented around this water basin. The Maritime Strategy for the Adriatic and Ionian Seas was adopted in 2012, incorporating a previous agreement of cooperation between coastal states stemming partly from European programmes (such as the IPA Cross-Border Cooperation Adriatic Programme and the Adriatic Ionian Initiative) within a framework of macroregional cooperation.

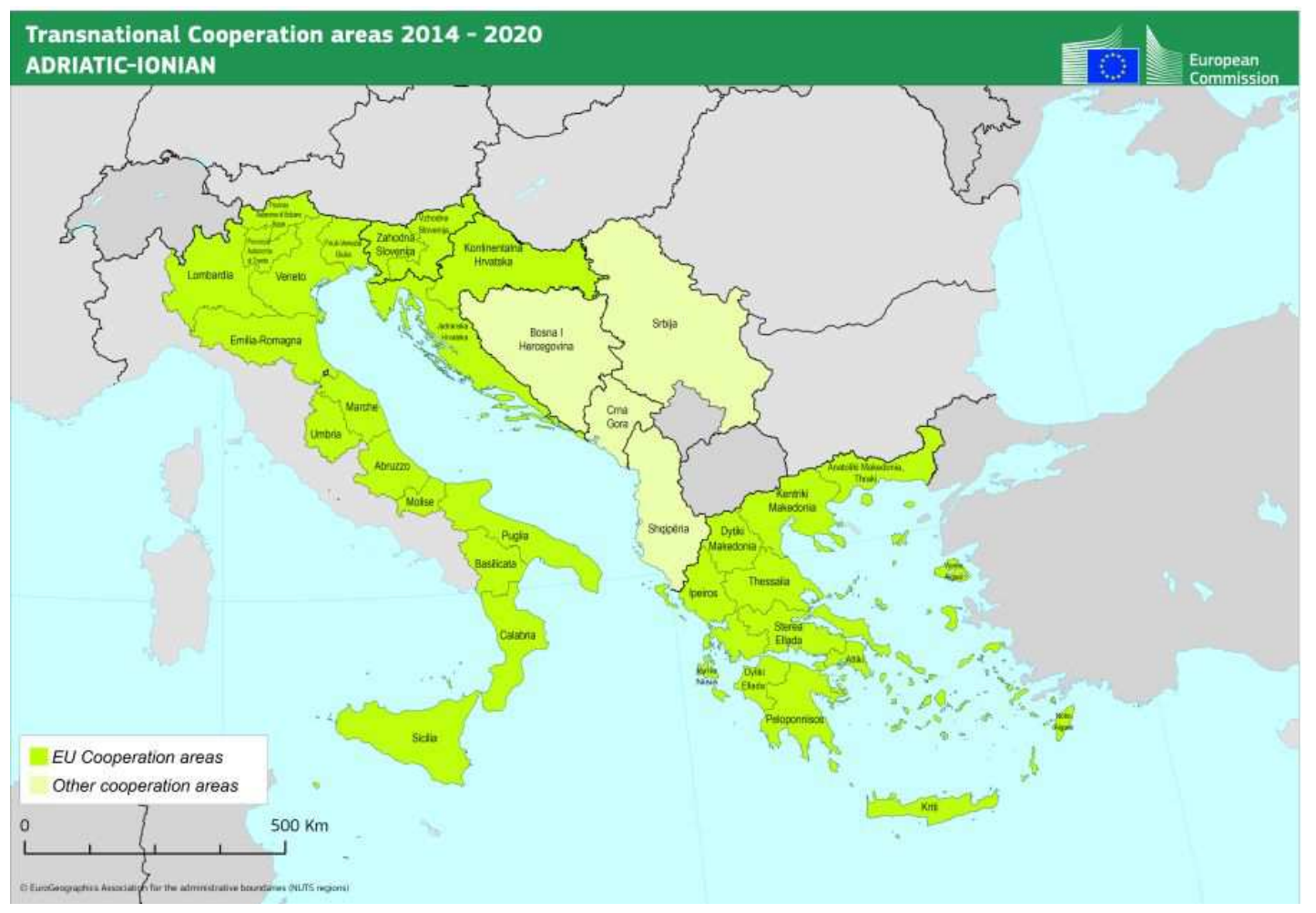

Figure 1 - The EU Adriatic and Ionian Maritime Region

The making of this Basin Strategy with the previous experiences of the macro-regions for the Baltic Sea and the Danube Region, "re-shuffled" the EU discussion about the European Union Strategy for the Adriatic and lonian Region (EUSAIR). As a consequence a new EUSAIR was adopted by the European Council in 2014. It was defined as a Macro-Regional Strategy that integrated Maritime Strategy into a wider purpose that extended beyond the maritime dimension, also covering 
the hinterland. Its four pillars were identified as: blue growth; connecting the region; preserving, protecting and improving the quality of the environment, and sustainable tourism. So, in few words, the Basin Strategy was designed in tandem with the new EUSAIR, in order to have a more complete approach to development, initiated from the maritime sphere and extended to the interior.

The particularity of EUSAIR (see Figure 1) is that it is the first Macro-Regional Strategy that incorporates a large number of non-EU countries (Albania, Bosnia and Herzegovina, Montenegro and Serbia) cooperating with EU countries (Croatia, Greece, Italy, and Slovenia). Nonetheless, the mentioned non-EU member states can be considered as candidates and potential candidates to join the Union. Hence, in some way EUSAIR holds also a sort of integrative power, providing a continuity to previous programmes, such as the 1999-2008 Stability Agreement for South-East Europe. In this perspective, EUSAIR has two potentialities: on the one hand, it can reinforce links among countries of a complex geographical area, recently affected by conflict, supporting the overcoming of the legacy of the past; on the other, it can strengthen the alignment of non-communitarian countries to EU normative mechanisms ('acquis communautaire'), favouring their path towards the Union.

The activities of the Action Plan are being developed in pairs: one EU country and one non-EU country (EU Commission, 2014):

> Greece and Montenegro work together on "Blue Growth": the aim is to drive innovative maritime and marine growth in the Region, by promoting sustainable economic development and jobs, and business opportunities in the Blue economy.

> Italy and Serbia cooperate on "Connecting the Region" (transport and energy networks). The aim is to improve transport and energy connectivity in the Region and with the rest of Europe. Here it is important to remember that Serbia does not have sea coast.

> Slovenia and Bosnia and Herzegovina work unite on "Environmental Quality". The aim is to address environmental quality through better cooperation at the level of the Region.

> Croatia and Albania work together on "Sustainable Tourism". The aim is to develop the full potential of the Region in terms of innovative, sustainable, responsible and quality tourism.

\section{Vulnerabilities of the EUSAIR Macro-Region}

As was identified by the 2014 EUSAIR policy driver, the Adriatic-Ionian Region faces a set of common challenges of differing natures. From socio-economic disparities (the countries involved have very different levels in terms of GDP per capita and unemployment), administrative and institutional issues (different legislation for accessing financial funds, corruption, cross-border crime and different speed of work), infrastructural deficit (accessibility problems such as poor connection, bottlenecks, lack of intermodal systems or maritime congestion) and energy difference (such as interconnection to electricity grid or limited capacity to exploit renewable energy sources).

However, a very sensitive side of this macro-region seems to be related especially to the ecological issue. Recently, particular attention has been directed to the environmental pressure and 
natural and man-made hazards that these two bodies of water (Adriatic and Ionian seas) are experiencing, as this is considered to be the most endangered area of the Mediterranean Sea (MedIAMER, 2014).

The shrinking of resources as a result of overfishing is a serious problem in both the Adriatic and Ionian Seas. In particular, the northern-central Adriatic Sea, has been affected by a dramatic expansion of marine capture fisheries since the early 1970s (FORTIBUONI et al., 2010). The northerncentral Adriatic area is considered one of the most productive areas of the Mediterranean Sea and is one of the major fishing grounds in southern Europe (SEVERINI, 2013). The increasing in fishing and the small mesh sizes had the main consequence of decreasing the average size of fish caught, slowing down the biomass growth and avoiding a sustainable recruitment.

The European Commission issued fishing rules in order to reduce the pressure on stocks and avoid further depletion, while facilitating the recovery of marine resources. Some of them limited the overall size of the fleet, the number of days at sea, regulated the mesh sizes for nets, etc. Fisheries Restricted Areas were also created; in these zones, fishing is limited or prohibited due to spawning or over-exploitation (GICALA \& SALVADOR, 2017).

A related threat is also represented by aquaculture, as it is an intensive industry that is responsible for discharging solids and chemical nutrients to the marine environment considered potentially degrading; aquaculture is also responsible for introducing alien species into the ecosystem.

Marine litter is another major environmental problem for the Adriatic and Ionian Seas, according to the marine litter assessment report released by the IPA-Adriatic funded DeFishGear project. This study estimate that $33-39 \%$ of the litter polluting these two seas, including their surface, seafloors and beaches, is produced from shoreline sources, mainly as a consequence of poor waste management practices, tourism and recreational activities, as well as from fisheries and aquaculture (17\%) (VLACHOGIANNI, et. al, 2017).

Water pollution caused by ships has also increased over the years, due to the intensification of traffic. Operational discharges from all ship types (cargo, tanker, ferry, passenger) includes bilge water from machinery spaces, fuel oil sludge, and oily ballast water from fuel tanks (LIUBARTSEVA et al., 2014). Ship traffic density, including cruise ships, is expected to increase in the Mediterranean Sea and in particular in the southern Adriatic and northern Ionian region (REMPEC, 2008).

The exploration of seabed mineral resources, especially hydrocarbon extraction, is also producing water pollution, and exploitation is resulting in oil spills (although incidents are decreasing, the number of offshore installations is expanding). The intense use of nitrates on agricultural land also pollutes the seawater.

Coastal development is also considered an important factor of environmental pressure for this macro-region. The Italian coast is particularly affected by a high level of urbanisation, with areas of intense tourism development and widespread congestion, as well as a constant reduction of natural environment. Uncontrolled and illegal coastal development is often a problem on both sides, leading to the destruction of habitats of local species. The eastern Adriatic presents a continuity of landscape 
and environmental heritage; nonetheless, the increasing threat of development processes, a lack of sewage and waste disposal systems and constant atmospheric emissions of polluting substances deriving from transport and industrial processes and combustible fuels for energy production are frequently detected in eastern Adriatic countries (Med-IAMER, 2014).

\section{From political ambitions to the practical reality: the need of a multi-scalar sustainability}

Environmental threats, as we have seen in the previous chapter, are diverse and intensified in this increasingly dense area of the Mediterranean Sea. Hence, the attention on ecological sustainability practices must be prioritised in the implementation of the EUSAIR.

Its Action Plan adopted in 2014 tried to address mainly two issues: the threat to coastal and marine biodiversity, and the pollution of the sea. The indicative actions of the plan aimed to protect the marine biodiversity focused on: increasing the marine knowledge, including monitoring and data sharing; enhancing the network of Marine Protected Areas through the designation of protected areas; exchanging best practices among managing authorities of Marine Protected Areas; implementing Maritime Spatial Planning and Integrated Coastal Management.

Regarding pollution of the sea, the indicative actions of the plan included: implementing a life cycle approach to marine litter through monitoring, promoting recycling and implementing preventive measures, especially for the abandonment of fishing gear; supporting clean-up programmes; implementation of measures to enable joint contingency planning and coordinated emergency response to oil spills; ensure prioritisation of investments to reflect the contribution to reducing pollution of the sea; addressing diffuse sources (e.g. nitrates from agriculture) through awarenessraising among farmers on the impacts of excessive use of fertilisers.

However, despite the good intention of the Action Plan, there is a discursive lack in the multiscalar approach to sustainability and its management methods. In such a macro-region, where countries have different infrastructures, regulations and socio-economic practices, it is important to rethink about a more compelling model for sustainability management, which must be able to observe and incorporate practices at different scales. Some experiences in Europe have shown that only focusing a top-down approach is not always the best model for reaching capillary-like sustainability; bottom-up environmental micro-management, can be key in this regard. This is especially true for fishing, a sphere that has suffered undesired effects from the application of top-down regulation (JENTOFT \& MCCAY, 1996).

The case of the introduction of the Environmental Management System (EMS) in Ireland is a good example of how community-led solutions can work effectively for environmental governance. The EMS was a voluntary auditing scheme designed to help Irish fishers to minimise their impact on the marine environment, where they were documenting different aspects of that impact. Engaging and negotiating with state and non-state actors and applying for international eco-accreditation, the involved lobster fishers managed (temporarily) to create a secondary market of "environmental" 
seafood (GUTHMAN, 2007), resisting their "less sustainable" competitors at home and abroad. In this case, the EMS attempted to resolve economic and environmental problems by encouraging fishers to work collectively by demonstrating that a biologically sustainable fishery could also be a profitable fishery (BRESNIHAN, 2018). As claimed by Povinelli (2011:9), "if we take neoliberal environmental governance to be characterised by the re-scaling of responsibility away from public institutions, the inclusion of difference, and the creative mobilising of individual agency, then it is possible to understand the proliferation of local, community-based initiatives as consistent with rather than alternative to late liberal forms of power".

Participatory modelling is another method emerging as a more transparent and effective management of natural resources (ROCKMANN et al., 2012; SHIRK et al.,2012). Even if the potential of participatory modelling to promote the sustainability of small-scale, artisanal marine fisheries has only been investigated in a handful of case studies (ARCULEO and LOBRUTTO, 2011; Trimble and BEKERS, 2013, 2015; GLASER et al., 2015; PITA et al., 2016), it appears as a possible solution to the failure of the singular top-down approach. The study of Maravelias et al. (2018) shows how seeking active stakeholder involvement throughout a participatory management process can offer a new comprehensive governance approach. Fishers are empowered (especially within the small-scale sector) through taking direct responsibility in the participative management of fisheries, build on the Mediterranean tradition of self-regulation.

\section{Conclusions}

One considers that the prosperity of the EUSAIR strategy is directly related to how successful it is in term of environmental sustainability, taking into account that "from this precondition depends social sustainability" (European Union, 2013).

For that reason, a stronger approach to explore and adopt new forms of sustainability management, based on small-scale good practices, participation and the creation of solid mechanism of transparency, can bring political ambitions closer to practical realities in this macro-region. This supports the search for better understanding and management of the impacts of the global on the local, while also highlighting the need to consider the kind of conflicts created from the combination of top-down directives and bottom-up approaches.

\section{References}

ARCULEO, M., and LO BRUTTO, S. (2011), "Growth and reproduction data of Plesionika narval (Decapoda, Caridea, Pandalidae) off the island of Ustica (southern Tyrrhenian Sea)", Crustaceana, 84:1367-1375.

BARROSO, J.M. (2007), "Key note speech - European Maritime Policy", Portuguese Presidency Ministerial Conference, Lisbon.

BRESNIHAN, P. (2018), "Revisiting neoliberalism in the oceans: Governmentality and the biopolitics of 'improvement' in the Irish and European fisheries", Environment and Planning A: Economy 
and Space 0(0) 1-22. 2018

EUROSTAT (2018), "Coastal regions: people living along the coastline, integration of NUTS 2010 and latest population grid". https://ec.europa.eu/eurostat/statisticsexplained/index.php/Archive:Coastal_regions__population_statistics

EU Commission (2014), "Sea basin regional strategy", Available at https://ec.europa.eu/maritimeaffairs/policy/sea_basins_en

EUROPEAN UNION (2013), Regulation (EU) No 1380/2013 of the European Parliament and of the Council of 11 December 2013 on the Common Fisheries Policy, amending Council Regulations (EC) No 1954/2003 and (EC) No 1224/2009 and repealing Council Regulations (EC) No 2371/2002 and (EC) No 639/2004 and Council Decision 2004/585/EC, L354/22. Official Journal of the European Union, L 354/22. http://data.europa.eu/eli/reg/2013/1380/oj.

FORTIBUONI, T., LIBRALATO, S., RAICEVICH, S., GIOVANARDI, O., SOLIDORO, C. (2010), "Coding early naturalists' accounts into long-term fish community changes in the Adriatic Sea (1800-2000)", PloSONE, 5 (11:15502).

GICALA, A. \& SALVADOR, R. (2017), "The EU Strategy for the Adriatic and the lonian Region: from Marginalisation to Co-Development", Proceedings of the "XI Congresso da Geografia Portuguesa. As Dimensões e a responsabilidade social da Geografia", Porto.

GUTHMAN, J. (2007), "The Polanyian way? Voluntary food labels as neoliberal governance", Antipode 39(3): 456-478.

JENTOFT, S. \& MCCAY, B. (1996), "From the bottom up: Participatory issues in fisheries management", Society and Natural Resources, 9: 237-250.

MARAVELIAS, C.D. VASILAKOPOULOS, P. KALOGIROU, S. (2018), "Participatory management in a high value small-scale fishery in the Mediterranean Sea", ICES Journal of Marine Science (2018), doi:10.1093/icesjms/fsy119

MED-IAMER (2014), "Adriatic Ionian Ecoregion (AIE)”. Available at Medmaritimeproject.eu

POVINELLI, E. (2011), "Economies of Abandonment: Social Belonging and Endurance in Late Liberalism", Durham, NC: Duke University Press.

REMPEC (Ed., 2002), "Protecting the Mediterranean Against Maritime Accidents and Illegal Discharges from Ships".

ROCKMANN, C., Ulrich, C., Dreyer, M., Bell, E., Borodzicz, E., Haapasaari, P., Hauge, K. H. et al. (2012), "The added value of participatory modelling in fisheries management-what has been learnt?", Marine Policy, 36: 1072-1085.

SEVERINI, N. (2013), "Management and overfishing problems in the High Adriatic sea and the future policy perspectives", Proceedings of the 2nd AIEAA Conference, Parma.

SHIRK, J. L., BALLARD, H. L., WILDERMAN, C. C., Phillips, T., Wiggins, A., Jordan, R., McCallie, E. et al. (2012), "Public participation in scientific research: a framework for deliberate design", Ecology and Society, 17: 29.

SVITLANA, P. L. DE DOMINICIS, M. ODDO, P. GREGGIO, N. ( ), "Oil spill hazard from dispersal of oil along shipping lanes in the Southern Adriatic and Northern Ionian Seas", Marine Pollution Bulletin 90(1-2):259-272.

TRIMBLE, M., and BERKES, F. (2013), "Participatory research towards co-management: lessons from artisanal fisheries in coastal Uruguay", Journal of Environmental Management, 128: 768-778.

VLACHOGIANNI T. AIKATERINI, A, ANASTASOPOULOU, B. FORFIBUONI, T. (2017), "Marine Litter Assessment in the Adriatic \& Ionian Seas 2017", http://mio-ecsde.org/wpcontent/uploads/2017/02/Final-MLA-pages_final.pdf 